\title{
Meningkatkan Keindahan Arsitektural Jembatan Surya Lembayung Kebun Raya Bogor dengan Tanaman Lanskap
}

\author{
RAY MARCH SYAHADAT ${ }^{1 *}$, PRIAMBUDI TRIE PUTRA ${ }^{1}$, TANDRI PATIH ${ }^{2}$ \\ 1Program Studi Arsitektur Lanskap, Fakultas Teknik Sipil dan Perencanaan, \\ Institut Sains dan Teknologi Nasional \\ 2Program Studi Tadris Matematika, Fakultas Tarbiyah dan Ilmu Keguruan, \\ Institut Agama Islam Negeri Kendari
}

*E-mail: ray.arl@istn.ac.id

\section{ABSTRACT \\ Improving the Architectural Beauty of Surya Lembayung Bridge at Bogor Botanical Gardens with Landscape Plant}

Surya Lembayung Bridge is one of bridge in the Bogor Botanical Gardens. Unlike the iconic bridges in the Bogor Botanical Gardens, the Surya Lembayung Bridge looks plain. Actually, the visual quality of the bridge can be increased with the addition of plants on either side of the bridge bodies. Therefore the visual quality needs to be assessed with a perceptional approach. The methods that used on this article were scenic beauty estimation, semantic differential, factor analysis, and multidimensional scaling. The results showed that the addition of plants in generally can improve the visual quality of the bridge. The highest visual quality is the bridge with the addition of Zephyranthes grandiflora.

Keywords: perception, scenic beauty estimation, multidimensional scaling, visual quality, Zephyranthes grandiflora

\section{Pendahuluan}

Kebun Raya Bogor merupakan salah satu pusat konservasi tanaman yang ada di Indonesia di bawah pengelolaan LIPI. Berdasarkan informasi yang dihimpun dari pengelola Kebun Raya Bogor, sejarah Kebun Raya Bogor dimulai sejak zaman kolonial. Mr. Reinwardt memiliki gagasan mendirikan sebuah kebun botani yang ia sampaikan kepada Baron Van Der Capellen, Komisaris Jenderal Hindia Belanda. Pemancangan patok merupakan kegiatan pertama yang menandai berdirinya Kebun Raya dengan nama 'S Lands Plantentiun te Buitenzorg (Pusat Konservasi Tumbuhan Kebun Raya - LIPI, 2017). Kebun tersebut didirikan di samping Istana Gubernur Jenderal di Bogor.

Letak Kebun Raya Bogor berada di jantung Kota Bogor dengan luas lebih kurang 87 ha. Sistem hidrologi Kebun Raya Bogor berasal dari Sungai Ciliwung dengan anak 
sungainya yaitu Sungai Cibatok. Kebun Raya Bogor pada dasarnya tergolong pada tipe ekosistem buatan yang memiliki sekitar 15.000 jenis koleksi tumbuhan. Bila diklasifikasikan lebih lanjut, jenis koleksi tersebut terdiri atas 3.504 spesies yang terbagi dalam 1.273 genus dan 199 famili. Seiring perkembangannya, Kebun Raya Bogor bukan hanya menjadi tempat konservasi tanaman, tapi juga menjadi tempat wisata. Klasifikasi Kebun Raya Bogor sebagai tempat wisata menurut Holden (2008) yaitu sebagai: (1) wisata alam, karena memiliki keindahan dan keunikan alam menjadi objek wisata utama; (2) tempat rekreasi, yang terlihat dari perannya dalam memulihkan kemampuan fisik dan mental serta mendapatkan kesempatan bersantai dan menghilangkan bosan; juga sebagai (3) wisata pendidikan, karena memperkaya informasi dan pengetahuan tentang objek wisata yang dikunjungi.

Dari sudut pandang wisata, nilai Kebun Raya Bogor akan bertambah jika di dalamnya dilengkapi beberapa atraksi wisata yang bisa menarik perhatian, estetik, namun tidak meninggalkan tema utamanya yakni konservasi tumbuhan. Kebun Raya Bogor memiliki beberapa jembatan yang digunakan untuk mempermudah akses di dalamnya. Salah satu jembatan yang belum lama terbangun yakni jembatan Surya Lembayung. Jembatan Surya Lembayung didirikan untuk mempermudah pengunjung yang menggunakan kendaraan mobil. Jembatan ini diresmikan pada tahun 2002 dan merupakan sumbangan dari Indofood. Dengan adanya Jembatan Surya Lembayung, pengunjung yang melewati Pintu 3 Kebun Raya Bogor, tidak harus melalui jembatan di Astrid Avenue terlebih dahulu (Ardyanto, 2017).

Berbeda dengan jembatan lainnya, Surya Lembayung cenderung sedikit memiliki nilai signifikansi karena beberapa faktor antara lain: (1) jembatan relatif baru sehingga nilai historisnya cenderung kecil; (2) jembatan ini diapit oleh dua jembatan (Jembatan Sempur dan Jembatan Gantung) yang lebih tersohor dan memiliki nilai estetika; (3) bentuk jembatan tidak memiliki keunikan tersendiri sebagaimana jembatan - jembatan yang ada di Kebun Raya Bogor (tidak memiliki unity). Jembatan yang terkesan hambar sebenarnya dapat dinaikkan nilai signifikansinya dengan penambahan tanaman pada sisi kiri dan kanan badan jembatan. Peran tanaman bukan hanya untuk melunakkan elemen yang terkesan keras, tapi juga dapat berperan sebagai objek atraksi yang estetik dan juga turut mengkonservasi tanaman. Peningkatan nilai estetika juga berpengaruh pada perilaku pengguna (Porteous, 1977). Oleh karena itu perlu dilakukan penilaian dengan pendekatan persepsional dari pengguna Kebun Raya Bogor. Studi ini diharapkan dapat menjadi rekomendasi untuk meningkatkan kualitas visual Jembatan Surya Lembayung sebagai sarana dan prasarana di Kebun Raya Bogor, serta mendukung Kebun Raya Bogor sebagai pusat konservasi tanaman dan tempat wisata di Kota Bogor.

\section{Metode}

Studi dilaksanakan selama Maret - Mei 2013 di Kebun Raya Bogor, Jawa Barat. Alat dan bahan yang digunakan antara lain kamera, alat tulis, kuesioner, software pengolah grafis Adobe Photoshop 7.0, serta software pengolah angka Microsoft Excel 2007, IBM SPSS Statistics 22, dan Minitab 16. Identifikasi masalah dilakukan dengan cara 
wawancara dan penelusuran sejarah dengan pengurus Kebun Raya Bogor. Setelah dilakukan wawancara dan penelusuran sejarah, ditemukan permasalahan di bidang estetika lingkungan terhadap Jembatan Surya Lembayung dengan kaitannya terhadap Kebun Raya Bogor sebagai tempat wisata.

Selanjutnya dilakukan pemotretan pada lokasi objek. Lima tanaman kemudian ditetapkan untuk digunakan dalam pengindahan arsitektural jembatan dengan pertimbangan holistik dari literatur. Objek yang telah dipotret dan lima jenis tanaman yang dipilih selanjutnya diolah dengan software pengolah grafis guna membuat enam skenario untuk penilaian estetika. Gambar dasar yang digunakan tidak berbeda baik angle maupun tone warna yang digunakan. Hal ini didasari perbedaan poin dan rute pemandangan dapat mempengaruhi persepsi seseorang (Bodnár, 2011). Dengan menggunakan gambar dasar yang sama, maka responden dapat fokus terhadap pengaruh tanaman terhadap keindahan arsitektural Jembatan Surya Lembayung.

Kuesioner disusun dan kemudian disebar kepada 34 responden pengguna Kebun Raya Bogor dengan latar belakang pendidikan arsitektur lanskap. Hal ini didasari oleh persepsi terhadap kualitas visual suatu lanskap ditentukan bukan hanya oleh interaksi yang kuat antara variabel visual lanskap (kedekatan emosional) tetapi juga pengetahuan pada objek visual lanskap itu sendiri (Nasar, 1988). Responden diminta mengisi tingkat keindahan arsitektural Jembatan Surya Lembayung dari skala 1-10, semakin tinggi nilai semakin tinggi kualitas keindahan begitupun sebaliknya. Responden juga diminta menilai objek dengan merujuk kepada dua puluh kata sifat bipolar yang telah ditentukan ditentukan guna mengetahui bagaimana persepsi pengamat mengenai desain skenario yang dibuat sebagai bentuk nilai kualitas.

Hasil survei kemudian diolah dengan software pengolah angka dan dianalisis. Daniel dan Boster (1976). Hasil dari SD kemudian dianalisis kembali dengan analisis faktor seperti yang pernah dilakukan Budiyono (2015), untuk mengetahui korelasi antara kelima lanskap tersebut. Analisis multidimensional scaling (MDS) juga dilakukan untuk memberikan gambaran pada pola kedekatan berupa kesamaan antara sekumpulan objek. MDS juga dapat menunjukkan dimensi penilaian langsung dari dari responden kepada pola visualisasi kedekatan mengenai kesamaan lanskap. Hal ini berbeda dengan analisis faktor yang melibatkan penilaian dari peneliti.

\section{Hasil dan Pembahasan}

Enam skenario desain jembatan yang ditetapkan yaitu Lanskap 1 tanpa tanaman atau kondisi eksisting, Lanskap 2 dengan tanaman Chlorophytum comosum, dan Lanskap 3 dengan tanaman Ipomea sp. Selanjutnya, Lanskap 4 dengan tanaman Crossandra infundibuliformis, Lanskap 5 dengan tanaman Zephyranthes grandiflora, dan Lanskap 6 dengan tanaman Epipremnum aureum (Gambar 1). Kelima tanaman yang digunakan atas pertimbangan mudah perawatan, banyak tersedia, murah, dan juga sesuai dengan kondisi lingkungan di sekitar jembatan (Mattjik, 2010a; Mattjik 2010b; Lestari dan Kencana, 2008; Lestari dan Kencana, 2015). 
Dari 34 kuesioner yang dinilai oleh responden, hanya 30 kuesioner yang diolah. Hal ini disebabkan oleh responden tidak mengisi kuesioner dengan lengkap. Gambar 2 menunjukkan nilai SBE. Terlihat bahwa Lanskap 1 dan 2 memiliki nilai SBE yang minus. Hal ini menunjukkan bahwa skenario tanpa tanaman dan penggunaan Chlorophytum comosum cenderung tidak disukai oleh responden. Penggunaan tanaman Chlorophytum comosum pada skenario Lanskap 1 ternyata malah menurunkan nilai SBE dibandingkan dengan skenario kontrol yakni jembatan tanpa tanaman (kondisi eksisting). Lanskap 1 dan 2 dapat dikategorikan dengan nilai estetika yang buruk karena nilai SBE berada $<-21$ (Daniel dan Boster, 1976).
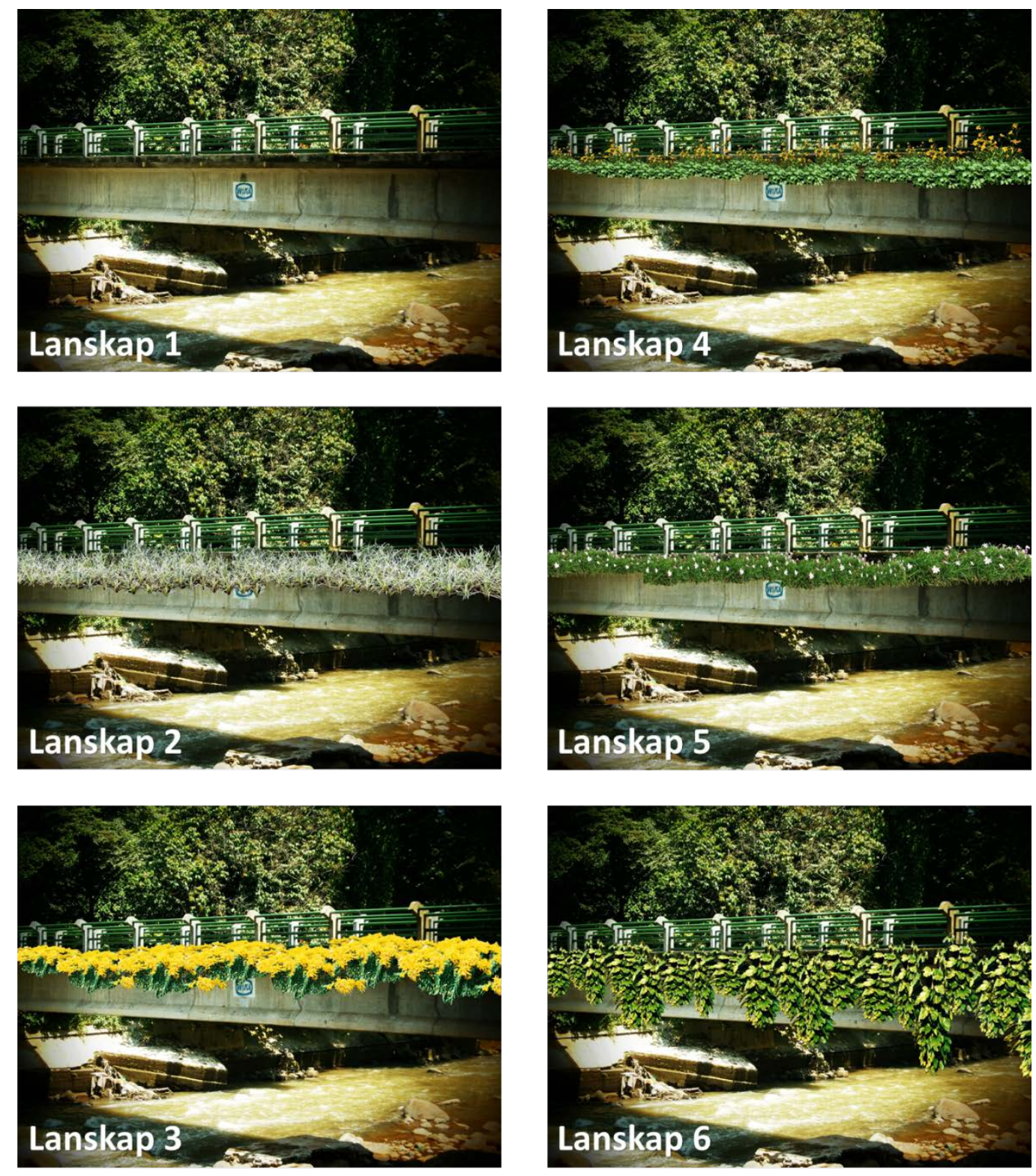

Gambar 1. Enam Skenario Desain Pada Jembatan Surya Lembayung

Hasil juga menunjukkan bahwa penambahan tanaman dapat meningkatkan keindahan arsitektural Jembatan Surya Lembayung sebab tanaman memiliki fungsi estetis disamping 
fungsi ekologis dan juga ekonomi (Chiang dan Tan, 2009). Dari fungsi estetis tanaman berperan sebagai pemuas kebutuhan rohani akan keindahan (Mattjik, 2010c). Hal ini dapat dilihat pada skenario Lanskap 3, Lanskap 4, Lanskap 5, dan Lanskap 6, yang menunjukkan nilai $\mathrm{SBE} \geq 0$. Skenario Lanskap 5 , dengan tanaman Zephyranthes grandiflora menunjukkan nilai SBE tertinggi $(48,345)$ yang kemudian disusul oleh skenario Lanskap 4 dengan tanaman Crossandra infundibuliformis, skenario Lanskap 6 dengan tanaman Epipremnum aureum dan skenario Lanskap 3 dengan tanaman Ipomea sp. Zephyranthes grandiflora disukai oleh responden diduga akibat dari morfologi bunga dan daun yang selaras dengan desain jembatan. Keterpaduan bunga dan daun pada tanaman hias dapat menimbulkan perhatian (Mattjik, 2010a). Semakin dikenal suatu tanaman, semakin mudah diposisikan sebagai penyemarak maupun pencipta suasana (Lestari dan Kencana, 2015).

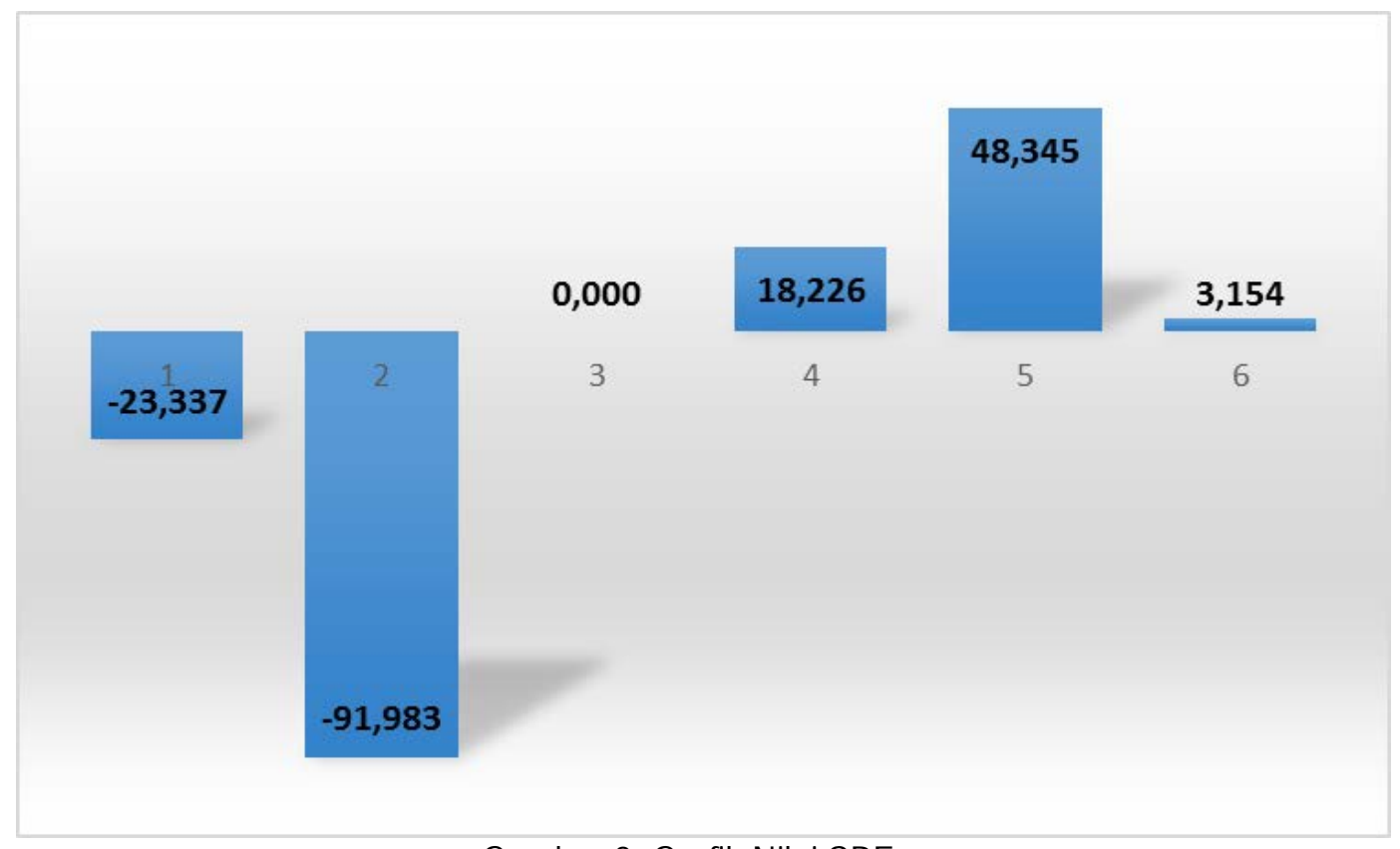

Gambar 2. Grafik Nilai SBE

Hasil analisis faktor menunjukkan bahwa terdapat tiga kelompok lanskap yang memiliki karakter lanskap yang mirip (Tabel 1). Kelompok 1 yaitu Lanskap 1 dan 6, kelompok 2 yaitu 4 dan 5 , serta kelompok 3 yaitu Lanskap 2 dan 3 (Gambar 3). Kelompok 1 mewakili desain tanaman yang terlalu ramai dan terlalu sepi. Hal ini ditunjukkan dari nilai korelasi pada Lanskap 1 sebesar -0.890 dan Lanskap 6 sebesar 0.884 . Kelompok 2 mewakili desain dengan tanaman berbunga yang mudah dikenang. Kualitas visual pada tanaman hias bunga dilihat dari warna, bentuk, ukuran, serta perpaduan antara petal, sepal, dan benang sarinya (Mattjik, 2010a). Selanjutnya, kelompok 3 mewakili desain tanaman hias daun yang kualitas visualnya menurut Mattjik (2010b) dilihat dari warna, bentuk, dan kilau. 
Tabel 1. Hasil Analisis Faktor

\begin{tabular}{ccccc}
\hline Variabel & Faktor 1 & Faktor 2 & Faktor 3 & Communality \\
\hline Lanskap 1 & -0.890 & 0.106 & -0.036 & 0.805 \\
Lanskap 6 & 0.884 & -0.041 & 0.233 & 0.837 \\
Lanskap 4 & 0.115 & 0.941 & -0.176 & 0.930 \\
Lanskap 5 & -0.340 & 0.887 & -0.036 & 0.904 \\
Lanskap 2 & 0.164 & -0.175 & 0.861 & 0.799 \\
Lanskap 3 & 0.078 & -0.033 & 0.858 & 0.744 \\
Variance & 17.359 & 17.179 & 15.663 & 50.201 \\
\% Var & 0.289 & 0.286 & 0.261 & 0.837 \\
\hline
\end{tabular}

Hasil MDS pada Gambar 4, menunjukkan bawa skenario lanskap yang memiliki nilai estetika yang tinggi berdasarkan hasil SBE khususnya pada Lanskap 4 dan 5 mewakili sifat elit (row 9) dan aman (row 16) menurut persepsi responden. Adapun sebarannya dapat dilihat pada grafik SD (Gambar 5). Ketiga skenario dengan nilai SBE tertinggi berdasarkan persepsi responden tersebut diduga akibat faktor psikologis responden yang tercipta apabila tanaman diaplikasikan pada Jembatan Surya Lembayung. Baskara (2011) menyatakan bahwa yang dimaksud dengan kenyamanan psikologis yaitu perasaan aman dari lingkungan dan terlindung dari iklim yang mengganggu.

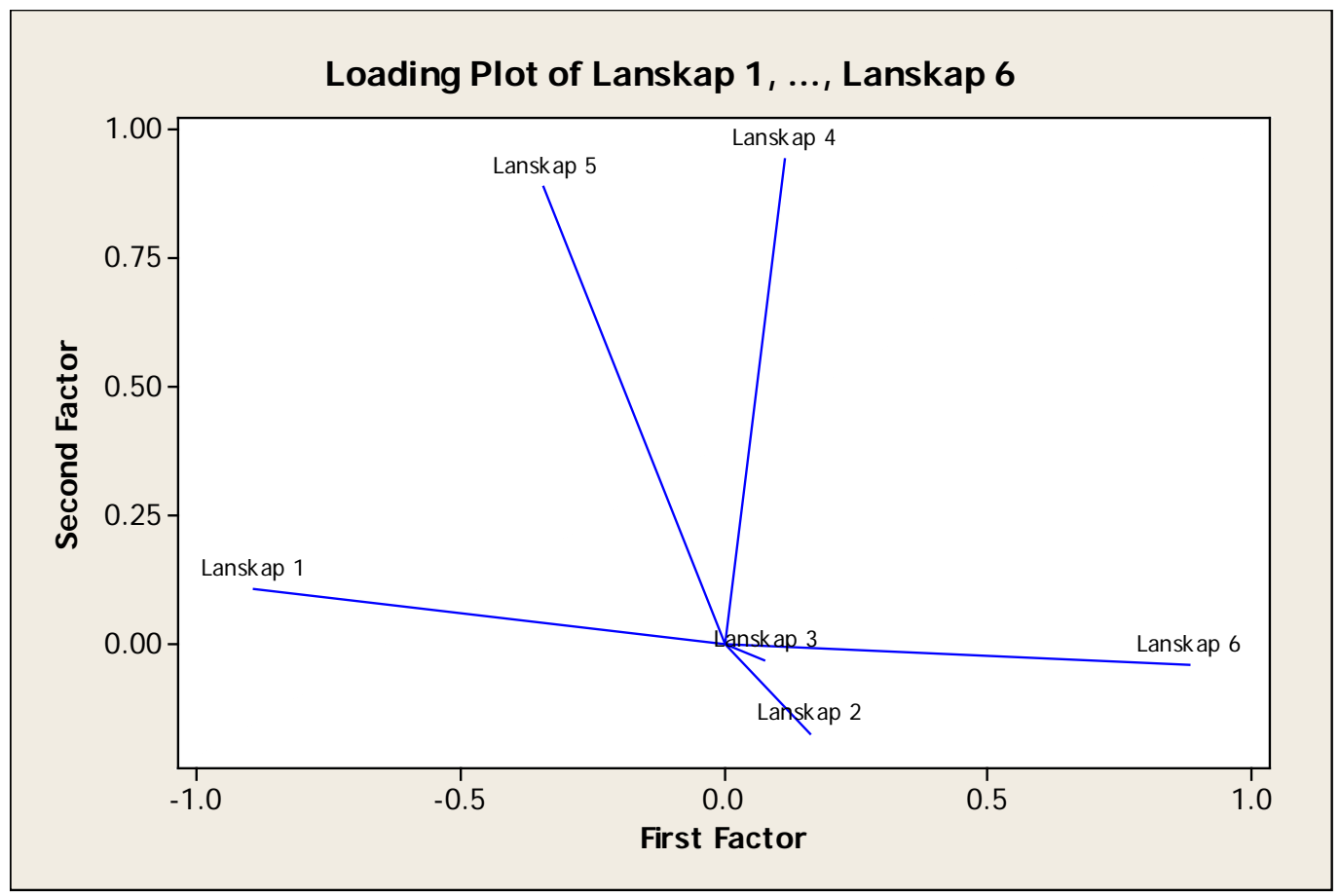

Gambar 3. Grafik Analisis Faktor Jembatan Surya Lembayung 


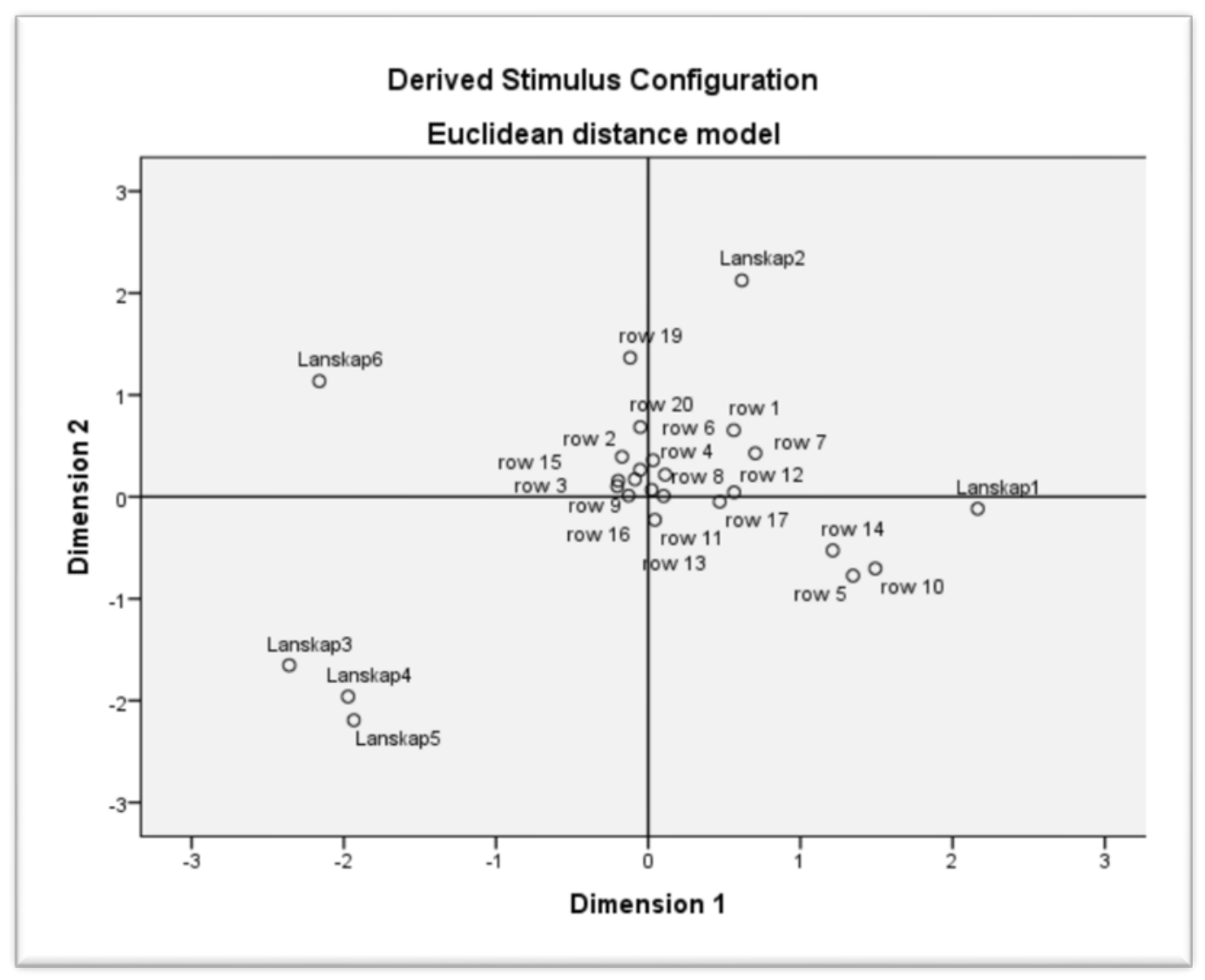

Gambar 4. Grafik MDS Jembatan Surya Lembayung

\section{Simpulan}

Secara umum penambahan tanaman dapat meningkatkan kualitas keindahan arsitektural Jembatan Surya Lembayung secara visual. Skenario penggunaan tanaman jenis Zephyranthes grandiflora menunjukkan nilai SBE paling tinggi, yang kemudian disusul oleh Crossandra infundibuliformis, Epipremnum aureum dan Ipomea sp. Lanskap dengan kualitas visual yang tinggi menurut responden mewakili sifat elit dan aman. 


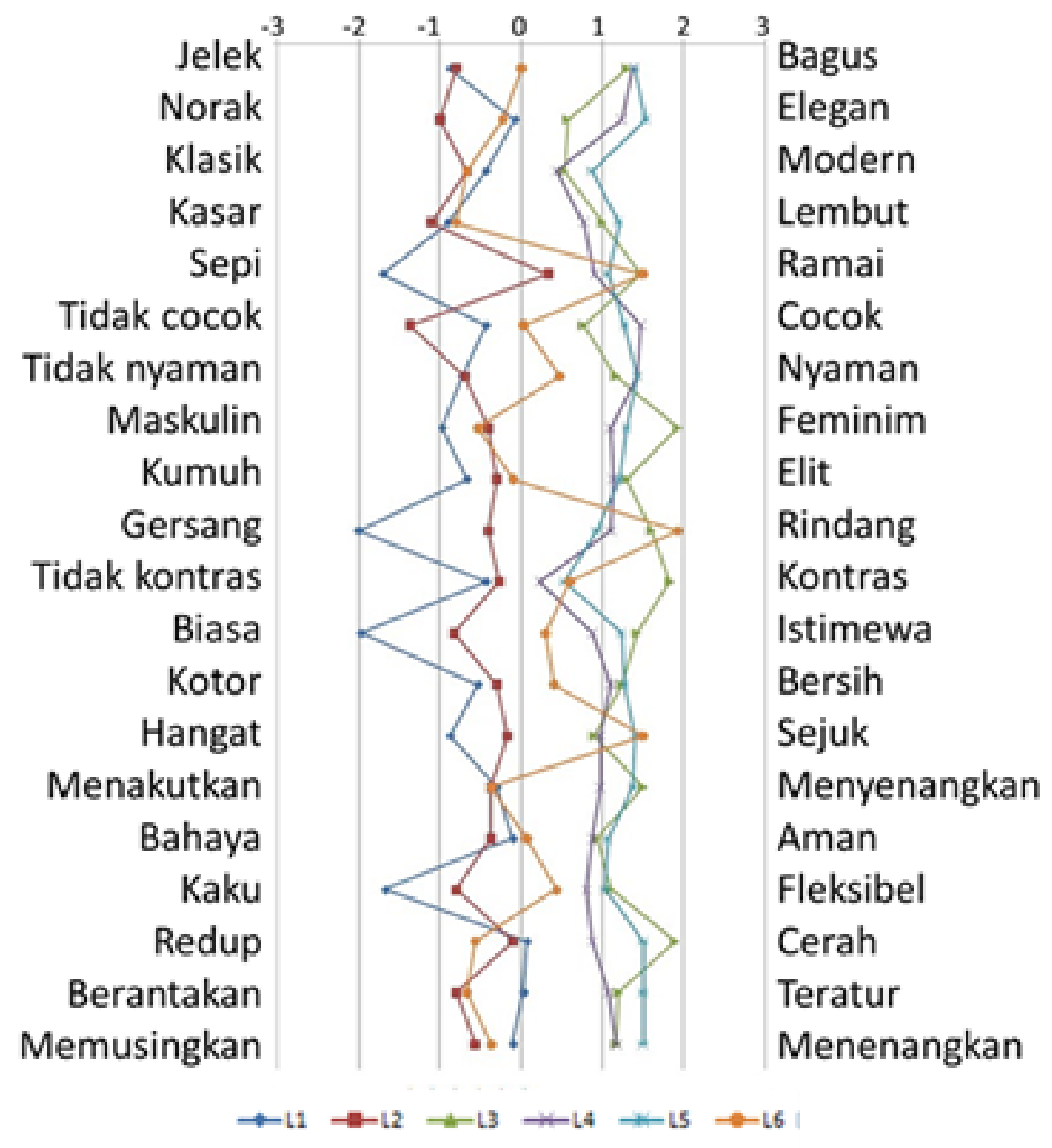

Gambar 5. Semantic Differential Jembatan Surya Lembayung

\section{Daftar Pustaka}

Ardyanto, A. 2017. Jembatan Surya Lembayung di Kebun Raya. Available online at www. lovelybogor.com/jembatan-surya-lembayung-di-kebun-rayal (accessed 12 January 2017).

Baskara, M. 2011. Prinsip Pengendalian Perancangan Taman Bermain Anak di Ruang Publik. Jurnal Lanskap Indonesia, 3(1):27-34.

Budiyono, D. 2015. Evaluasi Estetika Lingkungan Berdasarkan Persepsi di Welcome Area Kampus Institut Pertanian Bogor. Buana Sains, 15(1):19-28.

Bodnár, R.K. 2011. Tourist Aspects of Assessing Landscape Change. GeoJournal of Tourism and Geosites, 7(1):39-50.

Chiang, K \& A. Tan. 2009. Vertical greenery for the tropics. National Parks Board, Singapore. 
Daniel, C \& R.S, Boster. 1976. Measuring Landscape Aesthetic: The Scenic Beauty Estimation Method. USDA, New Jersey.

Holden, A. 2008. Environment and Tourism. Routledge, London.

Lestari, G. \& I.P. Kencana. 2008. Galeri Tanaman Hias Lanskap. Penebar Swadaya, Jakarta.

Lestari, G. \& I.P. Kencana. 2015. Tanaman Hias Lanskap. Penebar Swadaya, Jakarta.

Mattjik, N.A. 2010a. Tanaman Hias Bunga. In Tanaman Hias dan Bunga Potong. Edited by: Purwito, A. IPB Press. Bogor.

Mattjik, N.A. 2010b. Tanaman Hias Daun. Tanaman Hias dan Bunga Potong. Edited by: Purwito, A. IPB Press. Bogor.

Mattjik, N.A. 2010c. Pendahuluan. In Tanaman Hias dan Bunga Potong. Edited by: Purwito, A. IPB Press. Bogor.

Nasar, J.L. 1988. Environmental Aesthetics: Theory, Research, and Applications. University Press, Cambridge.

Porteous JD. 1977. Environment \& Behavior: Planning and Everyday Urban Life. AddisonWesley Longman Publishing Company, London.

Pusat Konservasi Tumbuhan Kebun Raya - LIPI. 2017. Sejarah Kebun Raya Bogor. Available online at http://www.krbogor.lipi.go.id/id/Sejarah-Kebun-Raya-Bogor.html (accessed 14 January 2017). 